\title{
Prevalence of and attitudes to waterpipe smoking among Saudi Arabian physicians
}

Mohammed Al Ghobain ${ }^{1}$, Anwar Ahmed ${ }^{2}$, Zynab Abdrabalnabi ${ }^{3}$, Wjdan Mutairi ${ }^{4}$ and Ali Al Khathaami ${ }^{1}$

${ }^{1}$ College of Medicine; ${ }^{2}$ College of Public Health and Health Informatics; ${ }^{4}$ College of Nursing, King Saud bin Abdulaziz University for Health Sciences, Riyadh, Saudi Arabia (Correspondence to: Mohammed Al Ghobain: alanezi@hotmail.com). ${ }^{3}$ Department of Medicine, King Abdulaziz Medical City, King Abdullah International Medical Research Centre, Riyadh, Saudi Arabia.

\begin{abstract}
Background: Tobacco smoking kills more than 5 million people annually and it is the most important cause of preventable death. Waterpipe smoking is common in the Middle East and is prevalent among young people. There is a misconception that it is less harmful than cigarette smoking. Physicians are considered role models in the community and their behaviours and attitudes towards smoking can have direct effects on cessation.

Aim: The aim of this study was to estimate current prevalence, attitudes and associated factors in regard to waterpipe smoking among Saudi Arabian physicians.

Methods: Using a self-administered questionnaire, we conducted a cross-sectional study among 454 male and female physicians from 3 specialties, and of various levels of training working in 4 hospitals in Riyadh.

Results: The prevalence of waterpipe smoking was $45 \%$, greater in men than in women (58\% vs $18 \% ; P \leq 0.001$ ) and in surgical than in medical specialists $(58 \%$ vs $38 \% ; P \leq 0.001)$. More non-smokers than smokers believed that physicians should serve as role models ( $79 \%$ vs $60 \% ; P \leq 0.001)$. Physicians who were waterpipe non-smokers had received more formal training about cessation than smokers ( $50 \%$ vs $36 \% ; P \leq 0.001$ ).

Conclusions: Waterpipe smoking among Saudi Arabian physicians is frequent and is associated with low exposure to information about the hazards and cessation during medical education.

Keywords: Smoking, Water-pipe, Saudi Arabia, Physicians, Medical Education

Citation: Al Ghobain M; Ahmed AE; Abdrabalnabi Z; Mutairi W; Khathaami AA. Prevalence of and attitudes to waterpipe smoking among Saudi Arabian physicians. East Mediterr Health J. 2018;24(3):277-282. https://doi.org/10.26719/2018.24.3.277

Received: 13/05/15; accepted: 6/03/17

Copyright $@$ C World Health Organization (WHO) 2018. Some rights reserved. This work is available under the CC BY-NC-SA 3.0 IGO license (https:// creativecommons.org/licenses/by-nc-sa/3.o/igo).
\end{abstract}

\section{Introduction}

Tobacco smoking in all forms kills more than 5 million people per year and it is the most important cause of preventable death (1). According to the World Health Organization, tobacco smoking is the second most common cause of death and the fourth most common risk factor for disease worldwide. If current trends continue, smoking will cause 8 million deaths per year by 2030 (1).

Waterpipe smoking, also known as shisha, hubblebubble, hookah, muassel or narghile, is another form of tobacco use which is common in restaurants and coffee shops in Middle East and many parts of the world in which young people commonly use this method of smoking. There is a misconception that waterpipe smoking is less harmful than cigarette smoking because the smoke passes through water and may be filtered by the water before it is inhaled. The World Health Organization issued a report in 2005 about waterpipe tobacco smoking and called for research on methods to evaluate smoker exposure and tobacco-smoking surveys among health professionals (2).

In Saudi Arabia, previous studies have reported the prevalence of waterpipe smoking in male medical students in central Saudi Arabia at 13\% (3) and in eastern
Saudi Arabia at $12.6 \%$ (4). Physicians are considered role models in the community, and their behaviours and attitudes towards smoking can have direct effects on smoking cessation. Physicians (medical doctors) are responsible for providing advice and education about quitting and preventing smoking. Previous studies on waterpipe smoking among Saudi Arabian healthcare professionals were limited to medical students in a single college or centre, and limited information is available about knowledge and attitudes towards waterpipe smoking in practising physicians. The objective of this study was to investigate the prevalence, attitudes and associated factors of waterpipe smoking among Saudi Arabian physicians working in 4 hospitals in Riyadh, Saudi Arabia.

\section{Methods}

\section{Sample size}

Sample size was calculated using the Raosoft sample size calculator (www.raosoft.com). The sample size was calculated by anticipating 30\% prevalence of waterpipe smoking with $z=1.96$ for a $95 \%$ confidence level, margin of error of $5 \%$. The minimum sample size required to estimate a population parameters was estimated ay 450 . 


\section{Survey}

We used a specific structured questionnaire modified from the Global Health Professional Survey, an international standardized questionnaire developed by the World Health Organization, the Centers for Disease Control and Prevention and the Canadian Public Health Association to collect information on tobacco use and cessation counselling among health professional students about smoking prevalence, characteristics (including waterpipe smoking), attitudes, perception, and exposure to smoking cessation training (5). The questionnaire had been previously translated and validated for a number of languages, including Arabic.

We carried out the survey during January and February 2015. Physicians were approached by data collectors (medical students) and the objectives of the study were explained. Physicians completed anonymous self-administered questionnaires during working hours in their workplace under the supervision of the medical students. Completing the questionnaire took an average of 15 minutes. The physicians were assured that the information provided would remain confidential and would be used only for the research purposes.

A current waterpipe smoker was defined as a physician who had smoked a waterpipe $\geq 1$ time in the previous 30 days.

\section{Participants}

A cross-sectional, anonymous, self-administered questionnaire was completed by Saudi Arabian physicians (medical doctors) who worked in 4 hospitals in Riyadh, Saudi Arabia (King Abdulaziz Medical City, King Fahad Medical City, King Khalid University Hospital, and Prince Sultan Military Medical City). We invited all male and female Saudi Arabian physicians from the 4 hospitals, covering 3 different specialties (medicine 52\%, surgery
$38 \%$ and family medicine $10 \%$ ) and different levels of training and expertise (intern, resident, fellow, assistant consultant and consultant) to complete the questionnaire until we reached the target sample size.

The study protocol was approved by the Ethical Research Committee of King Abdullah International Medical Research Centre and all hospitals involved in the study.

\section{Data analysis}

Data analysis was performed using SPSS statistical software. Sample characteristics were expressed as number (\%) or mean and standard deviation. The relations between waterpipe smoking and demographic characteristics such as age, sex, medical profession level, and medical specialty were evaluated with chi-square and t-test. Differences in attitudes and health education about waterpipe smoking across smoker status were evaluated using the t-test for independent samples.

Multivariate logistic regression analysis was used to test for risk factors associated with waterpipe smoking. Statistical significance was defined as $P \leq 0.05$.

\section{Results}

We approached around 600 Saudi Arabian physicians; 454 agreed to participate in the study an completed the questionnaires, a 75\% response rate (age range 22-56 years). Characteristics of the participants, including speciality and training, are detailed in Table 1.

We found that 204 physicians (45\%) were current waterpipe smokers (95\% confidence interval 40-50). A significantly higher prevalence of waterpipe smoking was found among males than females (58\% vs 18\%, P $\leq$ 0.001). Waterpipe smoking was more common among physicians who were surgical specialists $58 \%$ compared with $38 \%$ among the medical specialists and 35\% among

\begin{tabular}{|c|c|c|c|c|c|c|c|}
\hline \multirow[t]{2}{*}{ Characteristic } & \multicolumn{2}{|c|}{$\begin{array}{c}\text { Total } \\
(n=454)\end{array}$} & \multicolumn{2}{|c|}{$\begin{array}{l}\text { Waterpipe smokers } \\
\qquad(n=204)\end{array}$} & \multicolumn{2}{|c|}{$\begin{array}{l}\text { Waterpipe non-smokers } \\
\qquad(n=250)\end{array}$} & \multirow[t]{2}{*}{$P$-value } \\
\hline & No. & $\%$ & No. & $\%$ & No. & $\%$ & \\
\hline \multicolumn{8}{|l|}{ Sex } \\
\hline Women & 148 & 33 & 27 & 18 & 121 & 82 & \multirow[t]{2}{*}{$\leq 0.001$} \\
\hline Men & 306 & 67 & 177 & 58 & 129 & 42 & \\
\hline \multicolumn{8}{|l|}{ Training level } \\
\hline Intern & 110 & 24 & 53 & 48 & 57 & 52 & \multirow[t]{3}{*}{ NS } \\
\hline Resident & 199 & 44 & 97 & 49 & 102 & 51 & \\
\hline $\begin{array}{l}\text { Fellow, assistant } \\
\text { consultant, consultant }\end{array}$ & 145 & 32 & 54 & 37 & 91 & 63 & \\
\hline \multicolumn{8}{|l|}{ Medical specialty } \\
\hline Medical & 218 & 52 & 83 & 38 & 135 & 62 & \multirow[t]{3}{*}{$\leq 0.001$} \\
\hline Surgical & 160 & 38 & 93 & 58 & 67 & 42 & \\
\hline Family medicine & 43 & 10 & 15 & 35 & 28 & 65 & \\
\hline Mean (SD)age (years) & $31(7)$ & & $30(6)$ & & $31(8)$ & & NS \\
\hline
\end{tabular}

$N S=$ not significant $(P>0.05)$.

$S D=$ standard deviation . 
family medicine specialists $(P=0.001)$ (Table 1$)$. Most waterpipe smokers smoked at a coffee shop (41\%), with some at home $(27 \%)$ or in a restaurant $(13 \%)$. Of the 204 physicians who were waterpipe smokers, 157 (77\%) started smoking before age 24 years.

There were significant differences in attitudes and training between physicians who smoked and physicians who did not smoke waterpipes $(P \leq 0.001)$ (Table 2$)$. Compared with waterpipe smokers, a greater frequency of waterpipe non-smokers agreed that waterpipe sales and advertising should be banned; waterpipes should be banned in restaurants, coffee shops, and all enclosed public places; physicians should have specific training about techniques of cessation of waterpipe smoking; and physicians are role models who should advise and give information to patients about quitting waterpipe smoking (Table 2).

In regard to education during training programmes, waterpipe smokers received less education about the dangers of waterpipe smoking, had less discussion about the reasons that people smoke waterpipe and less teaching about the importance of recording waterpipe smoking history as a part of a patient's general medical history in comparison to waterpipe non-smokers $(P \leq$ $0.001)$ (Table 2). Half $(50 \%)$ of the non-smokers received formal training on cessation approaches during their medical school or residency training programmes compared with $36 \%$ among waterpipe smokers, $P \leq 0.003$ (Table 2).

Multivariate analysis showed there was a higher risk of waterpipe smoking in men than women [odds ratio $(\mathrm{OR})=4.6, P \leq 0.001]$; surgical than medical specialists $(\mathrm{OR}=2.0, \mathrm{P} \leq 0.001)$; physicians who had negative than positive attitudes about banning waterpipe smoking in restaurants $(\mathrm{OR}=3.9, P \leq 0.001)$ and coffee shops $(\mathrm{OR}=$ 7.6, $P \leq 0.001)$; and those who stated that physicians do not have a role in giving information about smoking cessation to patients $(\mathrm{OR}=2.5, \mathrm{P} \leq \mathrm{0.001})$ (Table 3 ).

\section{Discussion}

Our study provided insight about the prevalence and attitudes in regard to waterpipe smoking in Saudi Arabian physicians from 4 hospitals and different specialties in Riyadh, Saudi Arabia. We identified a high

\begin{tabular}{|c|c|c|c|c|c|}
\hline \multirow[t]{3}{*}{ Response } & \multicolumn{4}{|c|}{ Positive response } & \multirow[t]{3}{*}{ P-value } \\
\hline & \multicolumn{2}{|c|}{$\begin{array}{l}\text { Waterpipe smokers } \\
\qquad(n=204)\end{array}$} & \multicolumn{2}{|c|}{$\begin{array}{l}\text { Waterpipe non-smokers } \\
\qquad(n=250)\end{array}$} & \\
\hline & No. & $\%$ & No. & $\%$ & \\
\hline \multicolumn{6}{|l|}{ Attitude } \\
\hline Waterpipe sales should be banned & 109 & 53 & 211 & 85 & $\leq 0.001$ \\
\hline Complete ban on the advertising of waterpipe products & 141 & 70 & 225 & 90 & $\leq 0.001$ \\
\hline Waterpipes should be banned in restaurants & 113 & 55 & 233 & 93 & $\leq 0.001$ \\
\hline Waterpipes should be banned in coffee shops & 87 & 43 & 222 & 89 & $\leq 0.001$ \\
\hline Waterpipes should be banned in all enclosed public places & 149 & 73 & 230 & 92 & $\leq 0.001$ \\
\hline $\begin{array}{l}\text { Physicians should get specific training about techniques for } \\
\text { cessation of waterpipe smoking }\end{array}$ & 158 & 78 & 229 & 92 & $\leq 0.001$ \\
\hline $\begin{array}{l}\text { Physicians serve as role models for their patients and the } \\
\text { public }\end{array}$ & 123 & 60 & 198 & 79 & $\leq 0.001$ \\
\hline $\begin{array}{l}\text { Physicians should advise their patients who smoke } \\
\text { waterpipes to quit }\end{array}$ & 162 & 80 & 227 & 91 & $\leq 0.001$ \\
\hline $\begin{array}{l}\text { Physicians have a role in giving advice or information about } \\
\text { waterpipe cessation }\end{array}$ & 137 & 67 & 211 & 84 & $\leq 0.001$ \\
\hline $\begin{array}{l}\text { A patient's chances of quitting waterpipe smoking are } \\
\text { increased if physicians advise him or her to quit }\end{array}$ & 155 & 76 & 218 & 87 & $\leq 0.003$ \\
\hline \multicolumn{6}{|l|}{ Medical school curriculum or residency training } \\
\hline $\begin{array}{l}\text { Were you taught in any of your classes about the dangers of } \\
\text { waterpipe smoking? }\end{array}$ & 108 & 53 & 173 & 70 & $\leq 0.001$ \\
\hline $\begin{array}{l}\text { Did you discuss in any of your classes the reasons why people } \\
\text { smoke waterpipes? }\end{array}$ & 84 & 41 & 141 & 57 & $\leq 0.001$ \\
\hline $\begin{array}{l}\text { Did you learn that it is important to record waterpipe } \\
\text { smoking history as a part of the patient's general medical } \\
\text { history? }\end{array}$ & 132 & 65 & 198 & 80 & $\leq 0.001$ \\
\hline $\begin{array}{l}\text { Have you ever received any formal training in waterpipe } \\
\text { smoking cessation approaches to use with patients? }\end{array}$ & 73 & 36 & 123 & 50 & $\leq 0.003$ \\
\hline $\begin{array}{l}\text { Did you learn that it is important to provide educational } \\
\text { materials to support waterpipe smoking cessation to patients } \\
\text { who want to quit waterpipe smoking? }\end{array}$ & 88 & 43 & 156 & 63 & $\leq 0.001$ \\
\hline
\end{tabular}




\begin{tabular}{|c|c|c|}
\hline Variable & Odds ratio & $\begin{array}{c}95 \% \\
\text { confidence } \\
\text { interval }\end{array}$ \\
\hline Men vs women & 4.6 & $2.59-8.25$ \\
\hline Surgical vs medical specialty & 2.0 & $1.21-3.43$ \\
\hline $\begin{array}{l}\text { Waterpipes should not be banned } \\
\text { in restaurants }\end{array}$ & 3.9 & $1.61-3.43$ \\
\hline $\begin{array}{l}\text { Waterpipes should not be banned } \\
\text { in coffee shops }\end{array}$ & 7.6 & $3.28-3.43$ \\
\hline $\begin{array}{l}\text { Waterpipes should not be banned } \\
\text { in all enclosed public places }\end{array}$ & 0.2 & $0.08-0.64$ \\
\hline $\begin{array}{l}\text { Physicians do not have a role } \\
\text { in giving information about } \\
\text { waterpipe smoking cessation to } \\
\text { patients }\end{array}$ & 2.5 & $1.41-4.49$ \\
\hline
\end{tabular}

prevalence of waterpipe smoking among the physicians (45\%). Predictors of waterpipe smoking in our study were younger age, male sex and surgical specialty. Most of our participants started waterpipe smoking at high school or medical school age.

Although the data on waterpipe smoking in the Saudi Arabian population are limited, a pilot study among secondary school students in Al Hassa region showed a prevalence rate of $37 \%$ (6). The reported prevalence of current cigarette smoking among adults in Saudi Arabia ranges from $11.6 \%$ to $52.3 \%$ (7). Cigarette smoking among physicians and healthcare providers in Saudi Arabia has been studied previously. More recently, in southwestern Saudi Arabia $18.3 \%$ physicians were smokers, and the highest prevalence of smoking was seen among hospital residents $(25.3 \%)$, primary health care physicians $(20.5 \%)$ and hospital consultants (18.6\%) (8). In neighbouring countries, the frequency of tobacco smoking among physicians was $11 \%$ in Oman (9), $56 \%$ in Jordan (10) and $41 \%$ in Turkey (11). Waterpipe smoking is common in other Middle East countries: in a Syrian study, $25 \%$ of male students used waterpipes (12). In Lebanon, $21 \%$ of university students reported current waterpipe smoking (13). The introduction of flavoured tobacco, the thriving coffee shop culture and the lack of regulations have been cited as the main factors contributing for the spread of waterpipe smoking globally (14). The Global Youth Tobacco Survey Collaborative Group estimated that $10-18 \%$ of adolescents aged $13-15$ years use tobacco products other than cigarettes, mostly in the Eastern Mediterranean region (15).

\section{Funding: None.}

Competing interests: None declared.
The high prevalence of waterpipe smoking among Saudi Arabian physicians ( $45 \%$ ) is of concern because physicians are considered role models for their patients and the community in fighting tobacco consumption and promoting smoking cessation. There are several potential explanations for the high prevalence, including the high stress of a medical career and the misconception that waterpipe smoking relieves stress. Moreover, there is a belief that waterpipe smoking is less harmful than cigarette smoking $(16,17)$; other factors include curiosity and social trends as main reasons for waterpipe smoking (18). However, the low exposure to education related to waterpipe hazards and cessation in medical school or postgraduate training is probably the main contributing factor for the high frequency of waterpipe smoking among physicians. In our study, most physicians started waterpipe smoking at age under 24 years, and this is consistent with previous findings that most waterpipe smokers start smoking in adolescence (19). Waterpipe smoking is more prevalent in junior physicians (interns and residents) because these physicians are under severe stress and have very busy schedules. Our study showed a significantly higher prevalence of waterpipe smoking among men than women; this may be true, however it may be a result of underreporting by women because there is a social stigma associated with waterpipe smoking in women.

Limitations of the present study included the crosssectional design, which may have introduced bias from self-reporting. In addition, the study was limited to only one form of tobacco smoking. Nevertheless, the study had certain strengths: it was a multicentre study involving all levels of physicians with varying expertise and specialties.

There is a need to implement strategies to reduce waterpipe smoking among physicians, which should have the additional benefit of reducing waterpipe smoking in the general population. These strategies could include classes, training and educational materials about the health risks and cessation in medical schools and residency training programmes.

In conclusion, waterpipe smoking in Saudi Arabian physicians has high prevalence, especially in men, junior physicians, surgeons and physicians who did not receive formal education about waterpipe smoking in their training. This may result in a negative image of physicians because patients regard their physician as a model for health education and disease prevention. 


\section{Prévalence de la consommation de pipe à eau et attitudes à cet égard parmi les médecins en Arabie saoudite}

\section{Résumé}

Contexte : Le tabagisme tue plus de 5 millions de personnes par an et constitue la cause la plus importante de décès évitables. La consommation de pipe à eau est courante au Moyen-Orient et elle est prévalente chez les jeunes. Selon une idée reçue, elle serait moins dangereuse que la consommation de cigarettes. Les médecins sont considérés comme des modèles à suivre dans la communauté et leurs comportements et attitudes vis-à-vis du tabagisme peuvent avoir un impact direct sur le sevrage.

Objectif : La présente étude vise à estimer la prévalence actuelle, les attitudes et les facteurs associés à la consommation de pipe à eau parmi les médecins en Arabie saoudite.

Méthodes: En recourant à un questionnaire auto-administré, nous avons réalisé une étude transversale auprès de 454 médecins hommes et femmes de trois spécialités et de différents niveaux de formation, travaillant dans quatre hôpitaux de Riyadh.

Résultats : La prévalence de la pipe à eau s'élevait à $45 \%$; elle était supérieure chez les hommes que chez les femmes (58\% contre $18 \% ; p \leq 0,001)$ et chez les chirurgiens que chez les médecins (58\% contre $38 \% ; p \leq 0,001)$. Davantage de nonfumeurs que de fumeurs pensaient que les médecins devaient jouer un rôle de modèle ( $79 \%$ contre $60 \% ; p \leq 0,001)$. Les médecins qui ne fumaient pas la pipe à eau avaient suivi une formation plus formelle sur le sevrage tabagique que ceux qui la fumaient ( $50 \%$ contre $36 \% ; p \leq 0,001)$.

Conclusions : La consommation de pipe à eau chez les médecins saoudiens est fréquente et elle est associée à une faible exposition à l'information sur les risques et le sevrage tabagique durant la formation médicale.

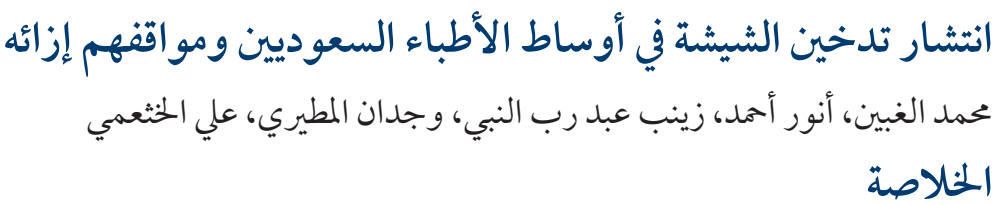

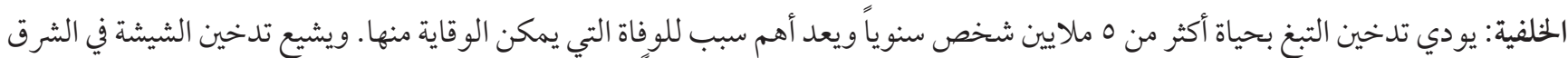

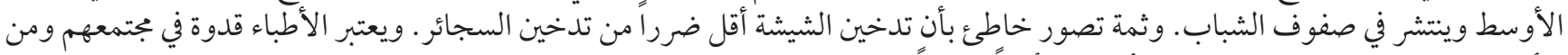

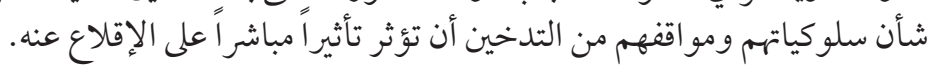

الهدف: تمثّل الهدف من هذه الدراسة في تقدير مستوى الانتشار الحالي لتدخين الشيشة بين أطباء المملكة العربية السعودية والمو اقف المتخذة حياله و العو امل المرتبطة به.

طرق البحث: أجرينا دراسة مقطعية، باستخدام استبيان يجاب عليه ذاتياً، لـ ع مه طع طبيباً وطبيبة من ب تخصصات، لديهم مستويات تدريب نختلفة

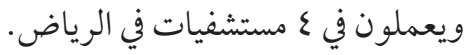

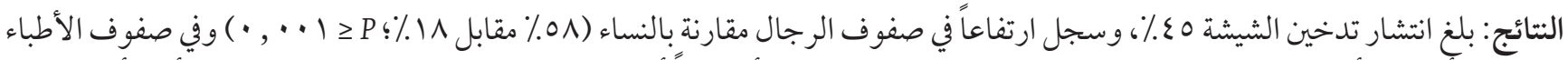

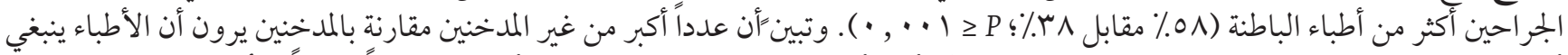

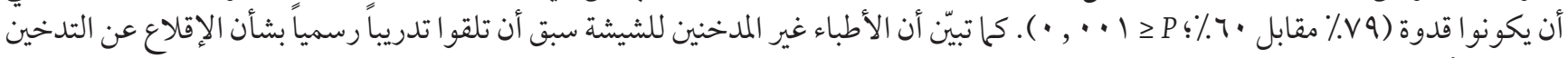

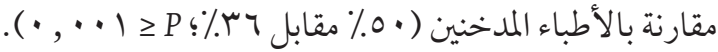

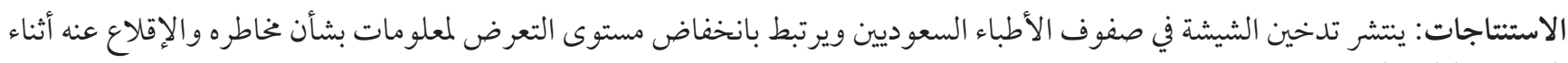
التدريب الطبي الذي يتلقونه.

\section{References}

1. Tobacco Free Initiative. Why tobacco is a public health priority. Geneva: World Health Organization; 2011 (http://www.who.int/ tobacco/health_priority/en/, accessed 28 November 2014).

2. WHO Study Group on Tobacco Product Regulation. TobReg - advisory note, waterpipe tobacco smoking: health effects, research needs and recommended actions by regulators. Geneva: World Health Organization; 2005.

3. Al-Turki YA. Smoking habits among medical students in Central Saudi Arabia. Saudi Med J. 2006;27:700-3. PMID:16680263

4. Taha AZ, Sabra AA, Al-Mustafa ZZ, Al-Awami HR, Al-Khalaf MA, Al-Momen MM. Water pipe (shisha) smoking among male students of medical colleges in the eastern region of Saudi Arabia. Ann Saudi Med. 2010;30:222-6. PMID:20427939

5. Tobacco Free Initiative. WHO/CDC Global Health Professional Survey. Geneva: World Health Organization; 2004 (http://www. who.int/tobacco/surveillance/ghps/en/, accessed 19 November 2017). 
6. Amin TT, Amr MA, Zaza BO, Kaliyadan F. Predictors of waterpipe smoking among secondary school adolescents in Al Hassa, Saudi Arabia. Int J Behav Med. 2012 Sep;19(3):324-35. PMID:21643931

7. Bassiony MM. Smoking in Saudi Arabia. Saudi Med J. 2009;30(7):876-81. PMID:19617999

8. Mahfouz AA, Shatoor AS, Al-Ghamdi BR, Hassanein MA, Nahar S, Farheen A, et al. Tobacco use among health care workersin southwestern Saudi Arabia. Biomed Res Int. 2013;2013:960292. PMID:24063018

9. Al-Lawati JA, Nooyi SC, Al-Lawati AM. Knowledge, attitudes and prevalence of tobacco use among physicians and dentists in Oman. Ann Saudi Med. 2009;29(2):128-33. PMID:19318747

10. El-Khushman HM, Sharara AM, Al-Laham YM, Hijazi MA. Cigarette smoking among health care workers at King Hussein Medical Center. J Hosp Med. 2008;3(3):281-4. PMID:18571808

11. Poyrazoğlu S, Sarli S, Gencer Z, Günay O. Waterpipe (narghile) smoking among medicaland non-medical university students in Turkey. Ups J Med Sci. 2010;115:210-6. PMID:20636256

12. Maziak W, Fouad FM, Asfar T, Hammal F, Bachir EM, Rastam S, et al. Prevalence and characteristics of narghile smoking among university students in Syria. Int J Tuberc Lung Dis. 2004;8:882-9. PMID:15260281

13. Tamim H, Terro A, Kassem H, Ghazi A, Khamis TA, Hay MM, et al. Tobacco use by university students, Lebanon, 2001. Addiction. 2003;98:933-9. PMID:12814499

14. Maziak W, Taleb ZB, Bahelah R, Islam F, Jaber R, Auf R, et al. The global epidemiology of waterpipe smoking. Tob Control. 2015 Mar;24(Suppl. 1):i3-12. PMID:25298368

15. Global Youth Tobacco Survey Collaborative Group. Tobacco use among youth: a cross-country comparison. Tob Control. 2002;11:252-70. PMID:12198280

16. Rezk-Hanna M, Macabasco-O'Connell A, Woo Ml. Hookah smoking among young adults in southern California. Nurs Res. 2014 Jul-Aug;63(4):300-6. PMID:24977727

17. Haroon M, Munir A, Mahmud W, Hyder O. Knowledge, attitude, and practice of water-pipe smoking among medical students in Rawalpindi, Pakistan. J Pak Med Assoc. 2014 Feb;64(2):155-8. PMID:24640803

18. Alvur MT, Cinar N, Akduran F, Dede C. Fallacies about water pipe use in Turkish university students - what might be the consequences? Asian Pac J Cancer Prev. 2014;15(5):1977-80. PMID: 24716921

19. Akl EA, Gunukula SK, Aleem S, Obeid R, Jaoude PA, Honeine R, et al. Prevalence of waterpipe tobacco smoking among the general and specific populations: a systematic review. BMC Public Health. 2011;11:244. PMID:21504559 